Historic, Archive Document

Do not assume content reflects current scientific knowledge, policies, or practices. 



\section{Special Holiday PLANT SALE}

T'o reduce our stock in certain items and secure further, room in our greenhouse for young plants, we are offering, from Thanksgiving to Christmas weeks inclusive, special reciuctions as follows:

HIBISCUS, DURANTAS, ACALYPHAS AND LAUREL CHERRIES, ranging from 2 feet to 4 feet in height, regular $\$ 1.00$ values, at $65 \mathrm{c}$ each.

CROTONS, extra heavy, fine colors, 2 feet to 3 feet high, regular $\$ 1.25$ value, only $75 \mathrm{c}$ each.

Besides the items above, this offer will include COCOS, WASHINGTONIA and PHOENIX PALMS, all CONIFEROUS EVERGREENS, AUSTRALIAN PINES, DWARF and ROYAL POINCIANAS, RUBBFR TREES, and red and purple BOUGAINVILLEAS, at $1-3$ off catalog price.

\section{COME AND MAKE YOUR SELECTION EARLY}

\section{Reasoner Brothers'}


Oneco, Fla. 
